Abstracta Iranica Abstracta Iranica

Revue bibliographique pour le domaine irano-aryen

Volume 27 | 2006

Comptes rendus des publications de 2004

\title{
L'inizio e il ritorno. Mabdâ' o Ma'âd. Traduzione, introduzione e note a cura di Demetrio Giordani, Milano, Mimesis, 2003, 153 p.
}

Fabrizio Speziale

\section{(2) OpenEdition}

1 Journals

Édition électronique

URL : http://journals.openedition.org/abstractairanica/6276

DOI : 10.4000/abstractairanica.6276

ISSN : 1961-960X

Éditeur :

CNRS (UMR 7528 Mondes iraniens et indiens), Éditions de l'IFRI

Édition imprimée

Date de publication : 15 mai 2006

ISSN : 0240-8910

Référence électronique

Fabrizio Speziale, "L'inizio e il ritorno. Mabdâ' o Maâd. Traduzione, introduzione e note a cura di Demetrio Giordani, Milano, Mimesis, 2003, 153 p. », Abstracta Iranica [En ligne], Volume 27 | 2006, document 277, mis en ligne le 02 janvier 2007, consulté le 25 septembre 2020. URL : http:// journals.openedition.org/abstractairanica/6276 ; DOI : https://doi.org/10.4000/abstractairanica.6276

Ce document a été généré automatiquement le 25 septembre 2020.

Tous droits réservés 


\title{
L'inizio e il ritorno. Mabdấ' o Ma'âd. Traduzione, introduzione e note a cura di Demetrio Giordani, Milano, Mimesis, 2003, 153 p.
}

\author{
Fabrizio Speziale
}

Le texte de D. Giordani se présente comme la première traduction intégrale dans une langue européenne d'un texte de Aḥmad Sirhindī (1564-1624), auteur et mystique indien dont l'ouvrage compte parmi les plus importantes et influents du soufisme indien d'époque moderne. Après le célèbre recueil de ses lettres (Maktūbāt-i Imām-i Rabbānī), le Mabdā' o ma'ād est probablement l'écrit sur la doctrine mystique le plus important composé par Sirhindì. L'ouvrage fut écrit en persan en 1019/1610, et son thème central est la description des sciences et des connaissances qui s'ouvrent au soufi engagé dans la voie naqshbandi. Sirhindī fait aussi de notables allusions de son ascension spirituelle, et à ses rencontres mystiques avec Bahā' al-Dīn Naqšband, 'Abd al Qādir al-Gīlānī et avec d'autres saints éminents. Les chapitres de ce bref traité décrivent dans une forme condensée et allusive les sujets centraux de la doctrine métaphysique, cosmologique et anthropologique de la Naqšbandiyya indienne, et en particulier de sa branche Mujaddidī ; thèmes qui se retrouvent après la synthèse opérée par Sirhindī dans plusieurs ouvrages d'autres importants auteurs indiens. L'ouvrage est accompagné d'une introduction sur la personnalité de l'A. et la thématique du traité : le traducteur établit une utile comparaison avec des passages des Maktūbāt concernant les sujets traités dans le Mabdā' o ma'ād. 
INDEX

Thèmes : 8. Soufisme

\section{AUTEURS}

FABRIZIO SPEZIALE

Université La Sapienza - Rome 